\title{
Rozstrzyganie sporów cywilnoprawnych w drodze decyzji administracyjnej przez Prezesa Urzędu Regulacji Energetyki
}

\begin{abstract}
1. Wstęp
Przedmiotem niniejszego artykułu jest rozstrzyganie przez Prezesa Urzędu Regulacji Energetyki (zwanego dalej Prezesem URE) w drodze decyzji administracyjnej spraw spornych określonych w art. 8 ust. 1 ustawy z dnia 10 kwietnia 1997 r. - Prawo energetyczne ${ }^{2}$. Zgodnie z tym przepisem Prezes URE rozstrzyga sprawy sporne dotyczące odmowy zawarcia umowy o przyłączenie do sieci, umowy sprzedaży, umowy o świadczenie usług przesyłania lub dystrybucji paliw lub energii, umowy o świadczenie usług transportu gazu ziemnego, umowy o świadczenie usługi magazynowania paliw gazowych, umowy o udostępnienie operatorowi systemu gazowego części instalacji używanej do magazynowania paliw gazowych, która jest niezbędna do realizacji jego zadań, umowy o świadczenie usługi skraplania gazu ziemnego oraz umowy kompleksowej. Ponadto organ ten jest właściwy w kwestiach nieuzasadnionego wstrzymania dostaw paliw gazowych i energii, odmowy przyłączenia w pierwszej kolejności instalacji odnawialnego źródła energii, a także odmowy przyłączenia mikroinstalacji, nieprzyłączenia mikroinstalacji pomimo upływu trzydziestodniowego terminu od dnia dokonania zgłoszenia przyłączenia mikroinstalacji oraz nieuzasadnionego ograniczenia pracy lub odłączenia od sieci mikroinstalacji ${ }^{3}$.
\end{abstract}

\section{Charakterystyka sporów rozstrzyganych przez Prezesa Urzędu Regulacji Energetyki}

Sprawy sporne, wymienione w art. 8 ust. 1 u.p.e., są ze swej natury sprawami cywilnoprawnymi. Stosownie do art. 1 ustawy z dnia 17 listopada

1 Mgr Angelika Kurzawa, Katolicki Uniwersytet Lubelski Jana Pawła II w Lublinie, Wydział Prawa, Prawa Kanonicznego i Administracji, Katedra Prawa Administracyjnego.

2 Tekst jedn.: Dz. U. z 2017 r. poz. 220 ze zm., dalej u.p.e.

3 Przepis niedawno zmieniony art. 2 pkt 4 ustawy z dnia 22 czerwca 2016 r. o zmianie ustawy o odnawialnych źródłach energii oraz niektórych innych ustaw, Dz. U. poz. 925. 
1964 r. - Kodeks postępowania cywilnego ${ }^{4}$ sprawą cywilną jest taka sprawa, w której stosunek prawny między stronami opiera się na równorzędności podmiotów i ekwiwalentności świadczeń, a zatem ze swej istoty jest sprawą cywilną (kryterium materialnoprawne), oraz taka, która $\mathrm{z}$ woli ustawodawcy jest rozpoznawana przez sąd cywilny (kryterium formalnoprawne) ${ }^{5}$. Zgodnie $\mathrm{z}$ art. $2 \$ 1$ k.p.c. do rozpoznawania spraw cywilnych, co do zasady, powołane są sądy powszechne, z zastrzeżeniem spraw, które przepisy szczególne przekazują do właściwości innych organów, o czym stanowi $\$ 3$ tego przepisu. Zatem art. $2 \$ 1$ k.p.c. ustanawia domniemanie drogi sądowej we wszystkich sprawach cywilnych, chyba że przepisy szczególne przekazują je do właściwości innych organów ${ }^{6}$. Przykładem takiego przepisu szczególnego jest właśnie art. 8 u.p.e., który wyłącza dopuszczalność drogi sądowej $\mathrm{w}$ sprawach wymienionych $\mathrm{w}$ tym przepisie, pomimo że sprawy te ze swej istoty są sprawami cywilnymi, przekazując ją do właściwości Prezesa URE. Stają się one w ten sposób sprawami administracyjnymi w znaczeniu formalnym, bowiem ze swej natury nie są sprawami administracyjnymi, ale zostały przekazane do właściwości organu administracji publicznej.

Prezesowi URE zostało zatem powierzone rozstrzyganie niektórych sporów cywilnoprawnych w sposób dla niego właściwy, czyli władczo i jednostronnie w drodze decyzji administracyjnej. Przez spór cywilnoprawny można rozumieć stosunek cywilnoprawny, w którym jedna ze stron tego stosunku ma określone roszczenie wobec drugiej strony, przy czym druga strona nie chce go spełnić zgodnie z żądaniem albo też w ogóle nie chce go spełnić. Stosunki cywilnoprawne, jak wiadomo, charakteryzują się równorzędnością podmiotów i swobodą wstępowania w nie oraz kształtowania tych stosunków. Natomiast decyzja administracyjna to akt administracyjny stanowiący władcze jednostronne oświadczenie woli organu, które rozstrzyga co do istoty sprawę indywidualną konkretnego podmiotu w sposób prawnie dla niego wiążący. Zgodnie $\mathrm{z}$ art. 8 u.p.e. Prezes URE rozstrzyga spory w sprawach, w których ustanowiony został publicznoprawny obowiązek przedsiębiorstwa energetycznego określonego działania, co uzasadnia wkraczanie administracji w sferę relacji cywilnoprawnych. Biorąc za przykład odmowę zawarcia umowy o świadczenie usług dystrybucji energii elektrycznej, należy zwrócić uwagę na art. 4 ust. 2 u.p.e. Zgodnie $\mathrm{z}$ tym przepisem przedsiębiorstwo energetyczne zajmujące się dystrybucją

4 Tekst jedn.: Dz. U. z 2016 r. poz. 1822 ze zm., dalej k.p.c.

5 J. Bodio [w:] Kodeks postępowania cywilnego. Komentarz, A. Jakubecki (red.), Warszawa 2015, s. 34. Do spraw cywilnych ze względu na kryterium materialnoprawne zalicza się sprawy ze stosunków z zakresu prawa cywilnego, rodzinnego i opiekuńczego oraz prawa pracy, zaś z uwagi na kryterium formalnoprawne m.in. sprawy z zakresu ubezpieczeń społecznych, ochrony zdrowia psychicznego czy przepisy o przedsiębiorstwach państwowych i samorządzie załogi przedsiębiorstwa państwowego.

6 Ibidem, s. 35. Por. postanowienie SN z dnia 16 marca 2000 r., I PKN 723/99, Legalis, a także postanowienie $\mathrm{z}$ dnia 4 lutego 2009 r., II PKN 226/08, Legalis. 
energii elektrycznej jest obowiązane zapewnić wszystkim odbiorcom oraz przedsiębiorstwom zajmującym się sprzedażą energii elektrycznej, na zasadzie równoprawnego traktowania, świadczenie usług dystrybucji energii, na zasadach i w zakresie określonym w ustawie, a świadczenie tej usługi odbywa się na podstawie umowy o świadczenie usług dystrybucji energii elektrycznej. Podobnie jest w przypadku odmowy przyłączenia do sieci. Stosownie do art. 7 ust. 1 u.p.e. przedsiębiorstwo energetyczne zajmujące się przesyłaniem lub dystrybucją paliw gazowych lub energii jest obowiązane do zawarcia umowy o przyłączenie do sieci, jeżeli istnieją techniczne i ekonomiczne warunki przyłączenia do sieci i dostarczania paliw gazowych lub energii, a podmiot ubiegający się o przyłączenie spełnia warunki przyłączenia do sieci oraz odbioru tych dóbr.

\section{Uprawnienie Prezesa Urzędu Regulacji Energetyki do kształtowania umów cywilnoprawnych}

Przepis art. 8 ust. 1 u.p.e. przyznaje Prezesowi URE kompetencję do rozstrzygania między podmiotami jedynie tych spraw spornych, które zostały wymienione $\mathrm{w}$ tym przepisie i nie może być on interpretowany rozszerza$\mathrm{jąco}^{7}$. Co ciekawe, w przypadkach odmowy zawarcia umowy organ ten jest uprawniony do kształtowania stosunku cywilnoprawnego między stronami, a także ustalania kształtu i treści (sic!) umowy cywilnoprawnej. W literaturze podkreśla się, że wydanie decyzji stwierdzającej obowiązek zawarcia umowy bez orzeczenia jej treści nie prowadzi do rzeczywistego rozstrzygnięcia sporu ${ }^{8}$. Zgodnie też ze stanowiskiem SA w Warszawie „Prezes URE, działając na podstawie art. 8 ust. 1 Prawa energetycznego mógł wydać decyzję orzekającą zawarcie umowy o określonej treści. (...) za przedstawioną wyżej wykładnią art. 8 ust. 1 Prawa energetycznego przemawia m.in. wzgląd praktyczny, tylko bowiem uznanie, iż Prezes URE ma uprawnienie do kształtowania treści umowy, którą mają zawrzeć strony, prowadzi do zlikwidowania sporu między nimi”" Prezes URE kształtuje umowę co do wszystkich jej postanowień, a więc zarówno w zakresie essentialia negotii, accidentalia negotii oraz naturalia negotii, a przede wszystkim postanowień stanowiących przedmiot sporu między stronami ${ }^{10}$. Należy bowiem mieć

7 J. Kędzia [w:] Prawo energetyczne. Komentarz, Z. Muras, M. Swora (red.), Warszawa 2010, s. 551.

8 P. Orzech, Z. Muras, J. Kędzia [w:] Prawo energetyczne. Komentarz, t. I, Z. Muras, M. Swora (red.), Warszawa 2016, s. 935-936; tak też J. Pokrzywniak, Wokót rozstrzygania przez Prezesa URE spraw spornych dotyczących odmowy zawarcia umowy, „Przegląd Ustawodawstwa Gospodarczego" 2009, nr 9, s. 12.

9 Wyrok SA w Warszawie z dnia 25 maja 2012 r., VI ACa 1510/11, Legalis.

10 Por. wyrok SN z dnia 9 marca 2004 r., III SK 18/04, Legalis, wyrok Sądu Antymonopolowego z dnia 4 grudnia 2000 r., XVII Ame 27/00, LEX nr 56344 oraz wyrok SOKiK z dnia 17 lipca 2002 r., XVII Ame 107/01, LEX nr 1727656. 
na uwadze, że z chwilą wszczęcia postępowania Prezes URE uzyskuje legitymację do ukształtowania spornej umowy między stronami, w granicach przysługującej stronom swobody kontraktowania, a sama decyzja zastępuje niejako oświadczenie woli stron w przedmiocie zawarcia umowy, analogicznie do art. 64 ustawy z dnia 23 kwietnia 1964 r. - Kodeks cywilny ${ }^{11}$. Należy zauważyć, że umowa to zgodne oświadczenie woli co najmniej dwóch stron, które zmierza do wywołania określonych skutków prawnych. Strony umowy są wobec siebie równorzędne i mają swobodę zarówno zawierania umów, jak i kształtowania ich treści, z zastrzeżeniem art. $353^{1}$ k.c., zgodnie z którym umowa nie może być sprzeczna z właściwością (naturą) stosunku prawnego, $z$ ustawą ani zasadami współżycia społecznego. Jednakże warto jeszcze raz zwrócić uwagę, że zawieranie umów, które wymienia art. 8 ust. 1 u.p.e., stanowi publicznoprawny obowiązek przedsiębiorstwa energetycznego, chyba że nie są spełnione przesłanki do zrealizowania tego obowiązku. Przykładowo przedsiębiorstwo energetyczne zajmujące się dystrybucją paliw gazowych może odmówić zawarcia umowy o przyłączenie do sieci, gdy żądający zawarcia umowy nie spełnia technicznych warunków przyłączenia do sieci i dostarczania paliw gazowych. Poza tym obowiązek ten ciąży na przedsiębiorstwie energetycznym na podstawie innych przepisów, m.in. art. 4 ust. 2 , art. $4 \mathrm{c}$ ust. 1 oraz 3 , art. 4 d ust. 1, art. 5a ust. 1 czy art. 7 ust. 1 u.p.e., a może także mieć swoją podstawę w koncesji udzielonej przedsiębiorstwu energetycznemu ${ }^{12}$.

Co warte podkreślenia, przepis art. 8 u.p.e. umożliwia Prezesowi URE kształtowanie umów jeszcze nie zawartych, gdy strony nie mogą dojść do porozumienia, a zatem a contrario nie może rozstrzygać w sprawach dotyczących już zawartych umów ${ }^{13}$. Przez „niedojście stron do porozumienia" należy rozumieć przypadki, gdy strony nie są w stanie uzgodnić treści przyszłej umowy albo przedsiębiorstwo energetyczne kwestionuje istnienie obowiązku zawarcia umowy ${ }^{14}$. Zgodnie zaś ze stanowiskiem SN w trybie art. 8 ust. 1 u.p.e. nie można dochodzić zmiany umowy, gdy zostały narzucone uciążliwe warunki, noszące znamiona praktyk monopolistycznych,

11 Tekst jedn.: Dz. U. z 2017 r. poz. 459 ze zm., dalej k.c. S. Gronowski, Prawo energetyczne. Wprowadzenie, orzecznictwo, przepisy wykonawcze, Warszawa 2000, s. 68. Tak też w wyroku Sądu Antymonopolowego z dnia 7 kwietnia 1999 r., XVII AMa 85/98/E, Legalis.

12 M. Nowaczek-Zaremba, Kompetencje Prezesa URE do zawierania umów cywilnoprawnych, „Biuletyn URE” 2007, nr 4, s. 75 oraz przytoczony tam wyrok Sądu Antymonopolowego z dnia 1 marca 2000 r., XVII Ame 53/99. SN również podzielił to stanowisko w wyroku z dnia 24 lipca 2002 r., I CKN 944/00, Legalis, oddalającym skargę kasacyjną na powyższe orzeczenie.

13 Wyrok SN z dnia 12 września 2003 r., I CKN 504/01, Legalis oraz wyrok SN z dnia 7 października 2004 r., III SK 56/04, Legalis. Zob. także G. Dylewska, R. Taradejna, Rozstrzyganie sporów przez Prezesa URE, „Biuletyn URE” 2005, nr 4, s. 47-49.

14 J. Kędzia [w:] Prawo energetyczne..., 2010, s. 552 oraz przywołane tam orzecznictwo. 
bowiem w tych sprawach właściwy jest Prezes Urzędu Ochrony Konkurencji i Konsumentów ${ }^{15}$. Dlatego też, stosownie do art. $65 \$ 1$ ustawy z dnia 14 czerwca 1960 r. - Kodeks postępowania administracyjnego ${ }^{16}$, Prezes URE po otrzymaniu wniosku w takiej sprawie powinien niezwłocznie przekazać go właściwemu organowi, zawiadamiając o tym wnioskodawcę. W przypadku zaś sporów wynikających z zawartych umów, np. odnoszących się do rozliczeń za dostarczoną energię elektryczną, paliwa gazowe albo ciepło, czy niezgodnego z prawem rozwiązania umowy właściwe są sądy powszechne ${ }^{17}$. Jak stwierdził SN: „Celem postępowania, o którym mowa w art. 8 ust. 1 (...) jest rozstrzygnięcie sporu co do tego, czy wstrzymanie dostaw energii było uzasadnione, a nie sporu co do wysokości wzajemnych wierzytelności stron umowy o dostarczanie energii elektrycznej"18. W przypadku zatem, gdy do Prezesa URE wpłynie wniosek o rozstrzygnięcie tego rodzaju sporu, powinien zwrócić go wnioskodawcy w drodze postanowienia, zgodnie $\mathrm{z}$ art. $66 \S 3$ k.p.a. ${ }^{19}$

\section{Charakter postępowania w sprawach $z$ art. 8 u.p.e.}

Postępowanie $\mathrm{w}$ sprawach określonych $\mathrm{w}$ art. 8 ust. 1 u.p.e. ma charakter kontradyktoryjny, co stanowi wyjątek na gruncie postępowania administracyjnego, bowiem to co do zasady jest inkwizycyjne. Tutaj natomiast mamy do czynienia z dwoma stronami o spornych interesach, a spór między nimi rozstrzyga trzeci podmiot - organ administracji publicznej. Do inicjatywy stron należy zarówno wszczęcie postępowania, jak i jego przedmiot, zaś Prezes URE nie może wszcząć postępowania z urzędu i jest związany treścią żąadania strony ${ }^{20}$. Nawet w razie wątpliwości co do zakresu żądania jego sprecyzowanie należy do strony, a nie do swobodnej oceny organu $^{21}$. Co więcej, w orzecznictwie wskazuje się, że postępowanie w trybie art. 8 u.p.e. jest zbliżone do powództwa o ustalenie stosunku prawnego, występującego na gruncie postępowania cywilnego. Zaś w następstwie złożenia wniosku o wszczęcie postępowania, w przypadku odmowy zawarcia umowy na podstawie art. 8 u.p.e. „Prezes URE uzyskuje ustawową legitymację do ukształtowania między stronami spornej umowy, w granicach przysłu-

15 Ibidem, s. 553.

16 Tekst jedn.: Dz. U. z 2016 r. poz. 23 ze zm., dalej k.p.a.

17 J. Skrago, R. Walaszczyk, Nie wszystkie spory z zakresu energetyki rozstrzyga Prezes URE, „Biuletyn URE” 2011, nr 1, s. 55-56.

18 Wyrok SN z dnia 4 marca 2004 r., III SK 8/04, Legalis.

19 Należy jednak pamiętać o $\$ 4$ tego przepisu, który stanowi, że jeżeli sąd powszechny uzna się za niewłaściwy w sprawie, organ nie może zwrócić wniosku. Analogiczny przepis znajduje się w art. $199^{1}$ k.p.c.

20 Por. wyrok Sądu Antymonopolowego z dnia 13 października 1999 r., XVII Ame $36 / 99$, Legalis.

21 Wyrok NSA z dnia 11 czerwca 1990 r., I SA 367/90, Legalis. 
gującej stronom swobody kontraktowania. Decyzja Prezesa URE, wydana w trybie art. 8 ust. 1 Prawa energetycznego, niejako zastępuje oświadczenie woli obu stron w przedmiocie zawarcia umowy (por. w drodze analogii art. $64 \mathrm{KC}$ ). Innymi słowy, do Prezesa URE odnoszą się te wszystkie ograniczenia odnoszące się do zasady swobody umów, które przysługują stronom (art. $353^{1} \mathrm{KC}$ ). W świetle tego przepisu, strony zawierające umowę mogą ułożyć stosunek prawny według swego uznania, byleby jego treść lub cel nie sprzeciwiały się właściwości (naturze) stosunku, ustawie ani zasadom współżycia społecznego. Decyzja Prezesa URE, o której mowa w art. 8 ust. 1 Prawa energetycznego, powinna zasadniczo orzec zawarcie między stronami odpowiedniej umowy, po uprzednim ustaleniu jej treści, chyba że brak jest w tej mierze technicznych i ekonomicznych warunków"22. Przy czym „Złożenie wniosku wszczynającego postępowanie administracyjne w sprawie zawarcia decyzją administracyjną spornej umowy nie daje stronie prawa do uzyskania decyzji w pełni uwzględniającej jej propozycje. Musi się ona bowiem liczyć z ewentualnością, że wobec braku zgody drugiej strony na proponowane postanowienia umowy, rozstrzygając spór Prezes URE weźmie pod uwagę szerszy kontekst gospodarczy wiążący się z zaspokojeniem określonych potrzeb energetycznych, a w szczególności zaś kryteria wskazane $w$ art. 1 ust. 2 Prawa energetycznego, takie jak wzgląd na: oszczędne i racjonalne użytkowanie paliw i energii, rozwój konkurencji, przeciwdziałanie negatywnym skutkom naturalnych monopoli, zapewnienie wymogów ochrony środowiska, czy też minimalizacja kosztów"23. Natomiast, jak była wyżej mowa, postępowanie administracyjne jest - co do zasady - inkwizycyjne, a zatem podmiotami tego postępowania są strona i organ administracji publicznej, który często wszczyna postępowanie $\mathrm{z}$ urzędu, określając przy tym jego zakres przedmiotowy.

\section{Strony postępowania}

Stronami postępowania $\mathrm{w}$ sprawach określonych $\mathrm{w}$ art. 8 ust. 1 u.p.e. są odbiorcy oraz przedsiębiorstwa energetyczne, a także prosumenci. Zgodnie $\mathrm{z}$ art. 3 pkt 13 u.p.e. odbiorcą jest każdy, kto otrzymuje lub pobiera paliwa lub energię na podstawie umowy z przedsiębiorstwem energetycznym. Natomiast przedsiębiorstwem energetycznym jest podmiot prowadzący działalność gospodarczą w zakresie wytwarzania, przetwarzania, magazynowania, przesyłania, dystrybucji lub obrotu paliwami albo energią albo przesyłania dwutlenku węgla stosownie do art. 3 pkt 12 u.p.e. Prosument zaś to odbiorca końcowy, który dokonuje zakupu energii elektrycznej na podstawie umowy kompleksowej oraz wytwarza energię elektryczną wyłącznie z odnawialnych źródeł energii w mikroinstalacji w celu jej zużycia

22 Wyrok Sądu Antymonopolowego z dnia 7 kwietnia 1999 r., XVII Ama 85/98/E.

23 Ibidem. 
na potrzeby własne, niezwiązane z wykonywaną działalnością gospodarczą regulowaną ustawą o swobodzie działalności gospodarczej ${ }^{24}$ (art. 2 pkt 27a ustawy z dnia 20 maja 2015 r. o odnawialnych źródłach energii ${ }^{25}$ ). Podmioty te, jako strony postępowania, mogą przy tym występować w różnych relacjach, a mianowicie stronami mogą być:

1) odbiorca i przedsiębiorstwo energetyczne,

2) prosument i przedsiębiorstwo energetyczne albo

3) przedsiębiorstwo energetyczne i przedsiębiorstwo energetyczne.

W spornym postępowaniu występuje odbiorca i przedsiębiorstwo energetyczne, gdy dotyczy ono np. odmowy zawarcia umowy o przyłączenie do sieci, umowy sprzedaży, umowy kompleksowej, umowy o świadczenie usług dystrybucji paliw lub energii czy też nieuzasadnionego wstrzymania dostaw. Prosument i przedsiębiorstwo energetyczne będą stronami postępowania, gdy przedmiotem sporu będzie odmowa przyłączenia do sieci mikroinstalacji, nieuzasadnione ograniczenie pracy lub odłączenie od sieci mikroinstalacji, jak również nieprzyłączenie do sieci mikroinstalacji, pomimo upływu trzydziestu dni od dnia dokonania zgłoszenia przyłączenia mikroinstalacji. Jeżeli zaś np. postępowanie będzie dotyczyć odmowy zawarcia umowy o świadczenia usług dystrybucji energii z przedsiębiorstwem zajmującym się sprzedażą energii czy umowy o magazynowanie paliw gazowych z przedsiębiorstwem zajmującym się sprzedażą paliw gazowych, stronami będą przedsiębiorstwa energetyczne ${ }^{26}$. Należy jednak zwrócić uwagę, że podmiotów występujących w postępowaniu może być więcej, np. odbiorca i przedsiębiorstwo energetyczne zajmujące się sprzedażą energii (sprzedawca) oraz przedsiębiorstwo energetyczne zajmujące się dystrybucją energii (operator systemu dystrybucyjnego) w sprawie o nieuzasadnione wstrzymanie dostaw, gdy została zawarta umowa kompleksowa ${ }^{27}$ (czyli umowa zawierająca postanowienia umowy sprzedaży i umowy o świadczenie usług przesyłania lub dystrybucji paliw gazowych lub energii, o czym stanowi art. 5 ust. 3 u.p.e.).

\section{Sposoby rozstrzygania sporów}

Jak już była wcześniej mowa, spory określone w art. 8 ust. 1 u.p.e. są rozstrzygane przez Prezesa URE w drodze decyzji administracyjnej. Treść decyzji zależy od konkretnej sprawy. I tak, w przypadku odmowy zawarcia umowy, gdy Prezes URE ustali, że w konkretnym przypadku istniał obo-

24 Ustawa z dnia 2 lipca 2004 r. o swobodzie działalności gospodarczej, tekst jedn.: Dz. U. z 2016 r. poz. 1829 ze zm.

25 Tekst jedn.: Dz. U. z 2017 r. poz. 1148 ze zm.

$26 \mathrm{~W}$ podanych przykładach będą to odpowiednio przedsiębiorstwa energetyczne zajmujące się: dystrybucją energii i sprzedażą energii oraz magazynowaniem paliw gazowych i sprzedażą paliw gazowych.

27 Patrz J. Kędzia [w:] Prawo energetyczne..., 2010, s. 555-556. 
wiązek zawarcia umowy, stwierdza w drodze decyzji obowiązek zawarcia umowy i określa treść umowy. Natomiast gdy sprawa dotyczy wstrzymania dostaw paliw gazowych i energii czy też ograniczenia pracy lub odłączenia od sieci mikroinstalacji, Prezes URE stwierdza w decyzji, czy wstrzymanie, ograniczenie lub odłączenie były uzasadnione albo też nieuzasadnione i zawiera $w$ treści decyzji odpowiednie postanowienia np. co do kontynuacji dostaw. Odnośnie do postępowania w sprawie odmowy przyłączenia w pierwszej kolejności instalacji odnawialnego źródła energii, odmowy przyłączenia mikroinstalacji albo też nieprzyłączenia mikroinstalacji pomimo upływu trzydziestu dni od dnia dokonania zgłoszenia przyłączenia mikroinstalacji, Prezes URE ustala, czy istnieje obowiązek przyłączenia. Jeżeli taki obowiązek ciąży na przedsiębiorstwie energetycznym, rozstrzygnięcie polega na stwierdzeniu istnienia obowiązku przyłączenia.

Warto również zauważyć, że postępowanie nie musi zakończyć się wydaniem decyzji merytorycznej, gdyż Prezes URE może wydać decyzję o umorzeniu postępowania na podstawie art. 105 k.p.a. Zgodnie $\mathrm{z} \$ 1$ tego przepisu organ wydaje decyzję o umorzeniu postępowania, gdy postępowanie z jakiejkolwiek przyczyny stało się bezprzedmiotowe, np. strony w toku postępowania w sprawie odmowy zawarcia umowy doszły do porozumienia i zawarły umowę, a także stosownie do $\$ 2$ na wniosek strony, która zainicjowała postępowanie, a pozostałe strony się nie sprzeciwiają i nie jest to sprzeczne $\mathrm{z}$ interesem społecznym.

Na marginesie trzeba wspomnieć o jeszcze jednym sposobie rozwiązania sporów wynikłych $\mathrm{w}$ sprawach określonych $\mathrm{w}$ art. 8 k.p.a., a mianowicie możliwości zawarcia ugody administracyjnej ${ }^{28}$. Stosownie bowiem do art. 13 k.p.a. sprawy, w których uczestniczą strony o spornych interesach, mogą być załatwiane w drodze ugody sporządzonej przez organ administracji publicznej. Ugoda taka wymaga zatwierdzenia w drodze postanowienia przez organ, przed którym została zawarta. Zatwierdzona ugoda wywiera takie same skutki jak decyzja administracyjna, o czym stanowi art. 121 k.p.a. Zawarcie ugody jest jednak dopuszczalne jedynie wówczas, gdy toczy się postępowanie przez organem administracji publicznej, przemawia za tym charakter sprawy, przyczyni się to do uproszczenia lub przyspieszenia postępowania i nie sprzeciwia się temu przepis prawa (art. 114 k.p.a.).

\section{Charakter decyzji rozstrzygających spory}

Decyzje wydawane przez Prezesa URE w sprawach spornych, określonych w art. 8 ust. 1 u.p.e., nie mają jednolitego charakteru. Część z nich ma charakter konstytutywny (prawotwórczy) i z chwilą ich uprawomocnienia się następuje skutek w postaci złożenia przez strony oświadczenia

28 R. Walaszczyk, Rozstrzyganie sporów w prawie energetycznym - zagadnienia praktyczne, „Biuletyn URE” 2009, nr 1, s. 37. 
woli, stosownie do art. 64 k.c. ${ }^{29}$ Decyzje na gruncie postępowania w sprawach z zakresu regulacji energetyki uprawomocniają się po upływie terminu do wniesienia odwołania, po oddaleniu odwołania przez sąd ochrony konkurencji i konsumentów, a w przypadku wniesienia apelacji, po uprawomocnieniu się orzeczenia sądu apelacyjnego. Do decyzji konstytutywnych zaliczyć należy te, które rozstrzygają o obowiązku zawarcia umowy, bowiem kształtują one stosunek prawny między stronami pozostającymi w sporze. W pozostałych przypadkach decyzje Prezesa URE mają charakter deklaratoryjny, gdyż jedynie stwierdzają zaistnienie określonego faktu, nie kształtując przy tym stosunku prawnego. Przykładowo decyzja merytoryczna kończąca postępowanie w sprawie nieuzasadnionego wstrzymania dostarczania paliw gazowych lub energii jedynie stwierdza, czy wstrzymanie dostaw było uzasadnione czy też nie. Podobnie w przypadku odmowy przyłączenia mikroinstalacji, gdzie Prezes URE w decyzji rozstrzyga o istnieniu lub nieistnieniu obowiązku przyłączenia.

\section{Zaskarżanie decyzji rozstrzygającej spór}

Od decyzji rozstrzygającej spór z art. 8 ust. 1 u.p.e. przysługuje stronom odwołanie w terminie dwutygodniowym od dnia doręczenia decyzji do sądu ochrony konkurencji i konsumentów, za pośrednictwem Prezesa URE, o czym stanowi art. $479^{47} \$ 1$ k.p.c. Prezes URE może przy tym w trybie samokontroli uznać odwołanie za słuszne i uchylić lub zmienić decyzję w całości lub w części. W tym przypadku nie przesyła akt sądowi, a jedynie bezzwłocznie powiadamia stronę, przesyłając jej nową decyzję, od której służy odwołanie (art. $479^{48} \$ 2$ k.p.c.).

Od wyroku SOKiK w przedmiocie rozstrzygnięcia odwołania przysługuje stronie apelacja do Sądu Apelacyjnego w Warszawie, stosownie do art. $367 \$ 1$ i 2 k.p.c., zaś od orzeczenia tego sądu przysługuje skarga kasacyjna do Sądu Najwyższego i to niezależnie od wartości przedmiotu sporu (art. $479^{56} \S 2$ k.p.c.).

\section{Postanowienie zabezpieczające}

Co więcej, warto wspomnieć o art. 8 ust. 2 u.p.e., który przewiduje możliwość wydania przez Prezesa URE postanowienia, w którym określi warunki podjęcia bądź kontynuowania dostaw paliw gazowych lub energii elektrycznej do czasu ostatecznego rozstrzygnięcia sporu, przy czym „ostateczne rozstrzygnięcie sporu" należy rozumieć w kontekście prawomocno-

29 H. Zadrożniak, Zakres obowiązku nałożonego na sprzedawcę z urzędu, „Biuletyn URE” 2014, nr 3, s. 26 oraz przytoczony tam wyrok Sądu Antymonopolowego z dnia 24 maja 2000 r., XVII Ame 23/00. 
ści decyzji ${ }^{30}$, a zatem gdy bezskutecznie upłynął termin do wniesienia odwołania albo gdy strona skorzystała z przysługującego jej odwołania i zapadło prawomocne orzeczenie sądu. Postanowienie to może być wydane jedynie na wniosek strony po wszczęciu postępowania oraz przed wydaniem decyzji w sprawie, który może być zgłoszony już we wniosku o rozstrzygnięciu sporu, jak i później w toku toczącego się postępowania ${ }^{31}$. Na wydane postanowienie nie przysługuje zażalenie i może ono być zaskarżone dopiero $\mathrm{w}$ odwołaniu od decyzji ${ }^{32}$. Jego celem jest zabezpieczenie interesów strony, w przypadku gdy druga wstrzymuje się ze swoim świadczeniem, a istnieje prawdopodobieństwo, że jej zachowanie jest nieuzasadnione ${ }^{33}$.

\section{Podsumowanie}

Decyzja administracyjna, która jest władczym jednostronnym oświadczeniem woli organu, będąca rozstrzygnięciem co do istoty sprawy administracyjnej, na gruncie spraw określonych w art. 8 ust. 1 u.p.e. stanowi rozstrzygnięcie sporu cywilnoprawnego. Innymi słowy, stosunek cywilnoprawny charakteryzujący się dobrowolnością i równorzędnością podmiotów jest kształtowany przez organ administracji publicznej, władczo i jednostronnie, w drodze decyzji administracyjnej, przez którą organ ten może narzucić podmiotom danego stosunku jego kształt i treść. Artykuł 8 u.p.e. jest przepisem szczególnym, wyłączającym właściwość sądów powszechnych w sprawach cywilnych. Należy jednak mieć na uwadze to, że $\mathrm{w}$ sporach wymienionych $\mathrm{w}$ tym przepisie na jednej ze stron tego stosunku ciąży publicznoprawny obowiązek wobec drugiej strony tego stosunku, przy zaistnieniu pewnych warunków. Trzeba podkreślić, że działalność $\mathrm{z}$ zakresu regulacji energetyki należy do usług z zakresu użyteczności publicznej i obowiązkiem państwa jest zapewnienie obywatelom dostępu do tych usług. Co więcej, w celu ochrony konkurencji na rynku energetycznym państwo musi zapewnić przedsiębiorstwom energetycznym równoprawne traktowanie. Dlatego też na przedsiębiorstwa energetyczne został nałożony publicznoprawny obowiązek świadczenia usług z zakresu energetyki i odmowa ich świadczenia może mieć miejsce jedynie w uzasadnionych przypadkach. Nie zmienia to jednak faktu, że spory określone w art. 8 ust. 1 u.p.e. ze swej natury są sprawami cywilnoprawnymi i ich rozstrzyganie przez organ administracji publicznej stanowi wyjątek od rozpozna-

30 J. Kędzia [w:] Prawo energetyczne..., 2010, s. 561.

31 R. Walaszczyk, Rozstrzyganie sporów w prawie energetycznym - zagadnienia praktyczne, „Biuletyn URE” 2009, nr 1, s. 32.

32 Takie stanowisko zostało zaaprobowane w doktrynie, tak m.in. F. Elżanowski, Prawnoprocesowa sytuacja przedsiębiorstwa energetycznego $w$ sprawach $z$ zakresu regulacji energetyki, Warszawa 2015, s. 187; J. Kędzia [w:] Prawo energetyczne..., 2010, s. 562; R. Walaszczyk, Rozstrzyganie sporów..., s. 32.

33 J. Kędzia [w:] Prawo energetyczne..., 2010, s. 560. 
wania takich spraw przez sądy powszechne. W literaturze wskazuje się, że wyłączenie kognicji sądów powszechnych w tych sprawach ma na celu powierzenie rozstrzygnięcia fachowemu i wyspecjalizowanemu organowi w sprawach energetycznych ${ }^{34}$. Warto zwrócić uwagę, że Prezesowi URE został przydany do pomocy urząd, w którym zatrudnieni są pracownicy mający nie tylko wykształcenie prawnicze, ale również techniczne, co pozwala im ocenić, czy np. zostały spełnione warunki przyłączenia do sieci i odbioru paliw gazowych lub energii w przypadku odmowy zawarcia umowy o przyłączenie do sieci. Natomiast sąd powszechny musiałby w tym celu powoływać biegłych, co generowałoby dodatkowe koszty i przedłużałoby czas trwania postępowania.

\section{Bibliografia}

Bodio J. [w:] Kodeks postępowania cywilnego. Komentarz, A. Jakubecki (red.), Warszawa 2015.

Czarnecka M., Ogłódek T., Prawo energetyczne. Komentarz, Warszawa 2012.

Dylewska G., Taradejna R., Rozstrzyganie sporów przez Prezesa URE, „Biuletyn URE” 2005, nr 4.

Elżanowski F., Prawnoprocesowa sytuacja przedsiębiorstwa energetycznego w sprawach $z$ zakresu regulacji energetyki, Warszawa 2015.

Gronowski S., Prawo energetyczne. Wprowadzenie, orzecznictwo, przepisy wykonawcze, Warszawa 2000.

Kędzia J. [w:] Prawo energetyczne. Komentarz, Z. Muras, M. Swora (red.), Warszawa 2010.

Nowaczek-Zaremba M., Kompetencje Prezesa URE do zawierania umów cywilnoprawnych, „Biuletyn URE” 2007, nr 4.

Orzech P., Muras Z., Kędzia J. [w:] Prawo energetyczne. Komentarz, t. I, Z. Muras, M. Swora (red.), Warszawa 2016.

Pokrzywniak J., Wokół rozstrzygania przez Prezesa URE spraw spornych dotyczacych odmowy zawarcia umowy, „Przegląd Ustawodawstwa Gospodarczego” 2009, nr 9.

Skrago J., Walaszczyk R., Nie wszystkie spory z zakresu energetyki rozstrzyga Prezes URE, „Biuletyn URE” 2011, nr 1.

Walaszczyk R., Rozstrzyganie sporów w prawie energetycznym - zagadnienia praktyczne, „Biuletyn URE” 2009, nr 1.

Zadrożniak H., Zakres obowiązku nałożonego na sprzedawcę z urzędu, „Biuletyn URE” 2014, nr 3.

\section{Streszczenie}

Celem niniejszego artykułu jest przedstawienie problematyki rozstrzygania sporów cywilnoprawnych przez Prezesa URE w drodze decyzji administracyjnej, na podstawie przepisów ustawy - Prawo energetyczne. Zgodnie z art. 8 ust. 1 u.p.e. Prezes URE jest

34 M. Czarnecka, T. Ogłódek, Prawo energetyczne. Komentarz, Warszawa 2012, s. 208. 
upoważniony do rozstrzygania spraw spornych wymienionych w tym przepisie, które są ze swej natury sprawami cywilnoprawnymi. Stosownie do art. $2 \$ 1$ k.p.c. sprawy cywilne rozpatrywane są przez sądy powszechne, z zastrzeżeniem spraw, które przepis szczególny przekazuje do właściwości innych organów, o czym stanowi $₫ 2$ tego przepisu. Takim właśnie przepisem szczególnym jest art. 8 u.p.e., który wyłącza dopuszczalność drogi sądowej w określonych sprawach spornych, przekazując je do rozstrzygnięcia Prezesowi URE. W sprawach spornych określonych w art. 8 u.p.e. z jednej strony mamy zatem spór stricte cywilnoprawny, a z drugiej strony organ administracji publicznej (centralny organ administracji rządowej), który ma rozstrzygnąć ten spór w sposób dla niego właściwy, korzystając ze swojego władztwa i nierównorzędności podmiotów. Stosunek cywilnoprawny charakteryzujący się dobrowolnością i równorzędnością podmiotów jest więc kształtowany przez organ administracji publicznej władczo i jednostronnie w drodze decyzji administracyjnej.

Słowa kluczowe: spór, sprawa cywilna, decyzja administracyjna, rozstrzyganie, Prezes Urzędu Regulacji Energetyki

\section{Resolution of Civil-Law Disputes by Means of the Administrative Decision of the President of the Energy Regulatory Office}

Abstract

The purpose of this article is to present the process of resolving civil-law disputes by the President of the Energy Regulatory Office by means of an administrative decision under the Energy Law Act. In accordance with the provisions of Article 8(1) of the Energy Law Act, The President of the Energy Regulatory Office is authorised to resolve disputes referred to in that provision which inherently belong to matters of civil law. Pursuant to Article 2(1) of the Code of Civil Procedure, civil matters are heard by common courts of law, except for those delegated to other bodies in special provisions referred to in Article 2(2). An example of such a special provision is Article 8 of the Energy Law Act, which excludes the admissibility of court proceedings in certain disputes to be resolved by the President of the Energy Regulatory Office. Thus, cases of disputes referred to in Article 8 of the Energy Law Act involve on the one hand a strictly civil law dispute and on the other a public authority (central government authority) which is to settle this dispute in a manner appropriate for it using its powers and non-equivalence of entities. Consequently, the civil-legal relationship characterised by voluntariness and equivalence of entities is shaped imperatively and unilaterally by a public authority by means of the administrative decision.

Keywords: dispute, civil matter, administrative decision, resolution, President of the Energy Regulatory Office 